\title{
Chapter 13 \\ Theorizing the Ukrainian Case: Pushing the Boundaries of Migration Studies Through a Europe-US Comparison
}

\author{
Cinzia D. Solari
}

\subsection{Introduction}

In the US-based migration literature, the Philippines and Mexico are prototypical examples of contemporary sending states and are perhaps the most researched. Among them, Ukraine may seem like odd company. Ukraine, once part of the Soviet Union, is differently positioned in the array of "modernization projects" from sending countries in Asia and Central and South America. However, on economic indicators, Ukraine, with $38 \%$ of its population below the poverty line, looks similar to Mexico at 40\%, and Ukraine might aspire to be the Philippines with its poverty rate of $30 \%$ (CIA 2011). Comparing the percentages of the population abroad in these three sending countries reveals that in 2010 the Philippines and Mexico had $4.6 \%$ and $10.7 \%$ of their total population abroad respectively, but Ukraine exceeded both countries with $14.4 \%$ of its total population abroad (Ratha et al. 2011: 178, 205, 249). These numbers suggest that Ukraine cannot be ignored as a sending country. Therefore, this chapter asks: What theoretical lessons does the Ukrainian case provide for the interdisciplinary field of migration studies?

This chapter suggests three insights that the Ukrainian case offers migration studies. First, Ukrainian migration highlights the importance of the transnational field as a key site for nation-state building. Ethnographic experiences with Ukrainian migrants in Italy are used to illustrate the agency of migrants working on the ground to build the "new" Ukraine from the outside in. Second, a comparison of migration streams to Italy and the United States leads to a consideration of the interactions between sending and receiving states that may produce contrasting migration

The original version of this chapter was revised. An erratum to this chapter can be found at DOI 10.1007/978-3-319-41776-9_14

C.D. Solari $(\bowtie)$

Department of Sociology, University of Massachusetts, Boston, MA, USA

e-mail: Cinzia.Solari@umb.edu 
patterns. These migration patterns both shape and explain contrasting migrant practices and subjectivities. Third, the comparison with key sending states such as Mexico and the Philippines demonstrates that Ukraine provides theoretical insight into the use of intersectional approaches to make sense of the gender/migration/ nation-state building nexus.

\subsection{Conducting a Global Ethnography}

In 2004-2006 I conducted participant observation and 158 in-depth interviews with Ukrainian migrants providing cleaning and caring services to the elderly in Rome, Italy and San Francisco, California, as well as community leaders such as priests, Ukrainian- and Russian-language newspaper editors, and union representatives of both migrant domestic workers and employers. I immersed myself in the Ukrainian community by attending church lunches, union meetings, cultural events, birthday parties, poetry readings and cultural performances. I also spent time in public spaces where Ukrainian migrants congregated. Several months into my fieldwork in Rome, the Orange Revolution began. I attended demonstrations and acts of solidarity with the protesters in Ukraine organized by Rome's Ukrainian community and waited in long lines with those attempting to cast their vote in the presidential election.

It soon became clear to me that in order to understand what was happening on the streets of Rome and San Francisco, I would have to walk the streets of Lviv, Ukraine. Italy and Ukraine are physically connected by Soviet-era courier vans transporting goods, money, pictures, foodstuffs and workers between Rome and seemingly every region of Ukraine on a weekly basis. For 3 days I rode with workers returning home to visit family. In Lviv, I conducted interviews with the children of migrants and reconnected with informants from Italy who were in Lviv for a visit home. I stayed with an informant in a rural village, tallied the households dependent on remittances from a family member abroad, and spoke informally with villagers. A global lens allowed me to explore ways of thinking through the individual-, meso- and macrolevel connections between Ukraine, Italy and the United States. Having conducted research in three countries, although necessary, is not what makes this project a global ethnography. Also required is the adoption of a global perspective through which global processes are understood as produced in local contexts by individual and institutional actors. This global analytical lens allows us to see that globalization can be excavated on the ground in locales that are the domain of ethnographers (Burawoy 2000). While the sending country can fall out of the analysis in migration studies, the perspective of global ethnography, I suggest, demands that migration scholars include the sending country in their studies and in their theorizing. In doing so, the transnational field becomes visible. 


\subsection{Transnational Nation-State Building: Ukrainian Migration to Italy}

As on many Sundays during my fieldwork with Ukrainian migrants in Rome, I took the metro to one of Rome's three Ukrainian Greek Catholic Churches (UGCCs). But this Sunday was different. This Sunday I would begin to understand the contours of Ukraine's transnational nation-state building process. I walked into the church and was surprised to look out onto a sea of orange. There were over 400 Ukrainian migrants, most middle-aged women labouring as domestic workers in Italy, wearing orange scarves and other orange paraphernalia. The crowd was showing solidarity with Viktor Yushchenko who, after questioning the integrity of the 21 November 2004 presidential election the previous week, sparked protests that came to be known as the Orange Revolution.

I saw an informant near the back of the church and went over to say hello. She introduced me to her friends and putting her arm around my shoulders told the group that I was there with her in St. Peter's Square this week when Pope John Paul II acknowledged the events in Ukraine saying, "Beloved, I assure you and all the Ukrainian people that I am praying these days in a special way for your dear homeland", a phrase I had heard repeated with satisfaction by Ukrainians all week. As the conversation changed to women reporting on phone calls with their children who had joined the protesters in city squares or other contacts on the ground in Kyiv, our attention was diverted to the parish priests. The priests solemnly processed into the church past a large orange flag with "Tak Yushchenko!" (Yes Yushchenko!) in large block letters and began the liturgy. Weeks later as the protests continued, Father Petro explained to me that the UGCC could not take sides in the contested presidential election. Yet when I asked about the reports of UGCC priests in Kyiv's Maidan Nezalezhnosti (Independence Square) supporting the protesters, he conceded, "The Church is on the side of truth and justice, and it happens that Yushchenko is also on the side of truth and justice"!

As I interviewed priests and parishioners over the following weeks I heard informants construct themselves as actors in Ukrainian nation-state building. In 2000 the UGCC had just two parishes or communities in Italy and by the Orange Revolution there were 90 and growing. Father Boryslav explained that creating Greek Catholic communities throughout Italy was about growing the Church, but it was also about creating a particular "national consciousness":

Well, the community gathering for lunch [in the church basement] after the liturgy was also a moment when we could sing our national songs. In this room, all the events that happened developed a national consciousness. You see the people that come here, the majority have lived through communism....[I]f before we started meeting and celebrating the liturgy people were afraid to tell Italians that they are Ukrainian - not Russian - and have a rich culture, afterwards they started to say "we are Ukrainian and our culture expresses itself in these ways". ${ }^{1}$

${ }^{1}$ During my field work, Italians frequently referred to all migrants from the former Soviet Union as "Russians". 
The UGCCs in Rome were not just for religiously minded migrants. They were also sites for Ukrainian migrants to find jobs, places to live, help with documents and, I discovered, sites for building particular cultural, ethnic and national visions of Ukraine that fuelled transnational political projects (Solari 2006a). Priests talked about teaching temporary labour migrants to be good Ukrainians as well as good Catholics so that they could return home to help build the new Ukraine. The women I interviewed in Rome realized they already were building the new Ukraine as transnational actors who, in the words of one informant, "carried Ukraine on their shoulders".

The media, especially in the context of Ukraine's current crisis, directs public attention to the complex national political scene inside Ukraine and highlights divisions between Eastern and Western Ukraine. Media coverage also draws the public's attention to the international scene in which Ukraine is a site where historical squabbles between Russia, the United States, and Europe are once again being played out. Perhaps this is because journalists, like many scholars, are influenced by what anthropologist Nina Glick Schiller (2009: 17) calls "methodological nationalism" or "an ideological orientation that approaches the study of social and historical processes as if they were contained within the borders of individual nation-states". Indeed in this international relations frame, nations are discrete, bounded entities. However, what the evidence suggests and the above vignette shows is that a national consciousness, what it means to be a "good Ukrainian", in the words of several of the UGCC priests I spoke with, is also being cultivated abroad in the expectation that flows of ideas and cultural products, what sociologist Peggy Levitt (2001) calls "social remittances", will accompany the movement of people. Defining a national identity is both about "who we are" and about "who we are not". With the largest migratory movements to Russia and Europe, what it means to be Ukrainian is being constructed through the collective juxtaposition of migrants moving between these locations both physically but also discursively. The transnational processes that accompany migration have a significant influence in shaping the sending country. This is especially visible in Ukraine at this historical moment of contested and competing national projects.

However, this study of Ukrainian migration to Italy and the United States suggests that not all migration patterns have the same effects in the sending country. When looking at a number of different countries, the unit of comparison is migration pattern, which is a structural and discursive system produced in the intersection of sending and receiving sites. It is a concrete naming of transnational space. Therefore, sending and receiving countries are in a dynamic relationship with each other. This is the second insight offered to migration studies by the Ukrainian case. Additionally, this comparison offers a different way to understand one of this volume's themes: beyond circulation. 


\subsection{Circular Versus Permanent: Interactions Between Sending and Receiving Sites}

Much of the theorizing about migration comes from studies conducted in receiving countries where immigrants come with their families to settle. The focus is on ways of measuring the assimilation and incorporation of immigrants along many variables, such as education and work outcomes, language acquisition or political participation. The underlying assumption is that immigrants leave their home country and settle in the receiving country. The dominant example of permanent migration is the case of Mexican immigration to the United States. This case has inspired much of the migration theory produced by US-based scholars, and some Europebased scholars have called for use of the Mexican case to illuminate facets of the "East-West migration" in Europe (Favell 2008: 702).

However, increased scholarly attention is currently being paid to circular or temporary labour migration. Ukrainian emigration to Europe highlights issues of temporality in migration. Scholars who look at temporary labour migration focus on the circulation of migrant labour (Parreñas 2010), the separation of the costs of reproducing workers borne by the sending country from the exploitation of cheap labour acquired by the receiving country (Burawoy 1976) and transnational mothering practices (Hondagneu-Sotelo and Avila 1997). The Philippines with its sexsegregated streams of migrant labour is the prototype of temporary labour migrations.

There is a bifurcation in migration studies between those who study the sending country and those who study migrants once they arrive in the receiving country, with the majority of scholars studying the latter (Levitt and Lamba-Nieves 2011). It is from the perspective of thinking solely about what happens to migrants in their places of destination, and therefore comparing receiving sites rather than migration patterns, that temporary versus permanent migration becomes a salient characteristic.

Ukraine is uniquely positioned as a sending country because it has both predominantly temporary migration streams to Europe and predominantly permanent migration streams to the United States, allowing for a comparison that complicates the at times simplified causal links between this one characteristic of a migration pattern and variation in migrant practices. The comparison between migration patterns from Ukraine to Italy and to the United States makes clear the limitations of reducing the concept of migration pattern to temporary versus permanent, which is just one structural characteristic of the overall migration pattern. We must move both "beyond circulation" and beyond settlement. Other structural and discursive factors must be taken into account in order to explain the variation in migrant practices and subjectivities discovered in global ethnographic studies of Ukrainian migration. For example, research suggests that older women, mostly grandmothers, led migrations to both Italy and the United States. The characteristic of temporary versus permanent tells us little about why most migrant sending countries send young women, but Ukraine sends older women. 
Table 13.1 Characteristics of migration patterns from Ukraine to Italy and the United States

\begin{tabular}{l|l}
\hline Italy & United States \\
\hline Temporary migration & Permanent migration \\
\hline Individual women (grandmothers) & Family migration/family reunification \\
\hline Undocumented/temporary visas & Documented \\
\hline Constitutive of nation-state building & Peripheral to nation-state building \\
\hline
\end{tabular}

Analytically, gendered relations can be seen from a feminist and global perspective as a way of naming power, both at the level of individual interactions, and as the terrain on which relations between groups and nations are articulated. From this perspective, Ukraine as a sending country intersects with both Italy and the United States to produce different migration patterns, and it is the comparison of migration patterns that makes Ukrainian emigration such a sociologically interesting case. These migration patterns have both structural and discursive dimensions. Some of the structural characteristics of these two migration patterns are listed in Table 13.1.

The structural dimension refers to the institutional architecture of the migration pattern. This includes whether the migration pattern is temporary or permanent, whether migrants are documented or undocumented, and whether they migrate as individuals or in family units. Migration patterns also have different discursive terrains, but here this dimension will only be briefly alluded to. For example, the Ukrainian state produces different emigration discourses labelling migrants to Italy "prostitutes" and those to the United States "defectors" (Solari 2014). This shapes the practices of both migrants and non-migrants and ultimately leads to the production of different migrant subjectivities. These findings suggest that temporary versus permanent migration is just one characteristic of a larger migration pattern. There is much to consider analytically "beyond circulation".

Using migration patterns as the unit of analysis highlights transnational processes because consideration is focused simultaneously on both sending and receiving countries. This does not mean, however, that whether a migration is temporary or permanent does not have any explanatory value or is unimportant. Some scholars find that temporary labour migrants tend to be more oriented toward the sending country, whereas permanent settlers are more oriented toward the receiving country. Others suggest that even permanent settlers may keep active transnational ties (Levitt and Schiller 2004; Portes et al. 2007). In receiving countries, whether a migration is temporary or permanent can also highlight the role of immigration laws and labour demands in shaping structural aspects of the migration pattern. Ukrainian migrants to Italy enter on tourist visas and overstay them. The Italian state recognizes that, given its ageing population and low birth rate, it has a "care crisis" with respect to its elderly. As a result, the Italian state has passed various amnesty laws to grant temporary work visas to migrant care workers in particular. The precariousness of their legal status shapes structural aspects such as the mobility of migrants and their ability to bring family with them. Immigration laws in the United States, in contrast, privilege family reunification and settlement. Those who had a family sponsor or who won a green card for lawful residence in the "green card lottery" 
were able to bring unmarried minor children and spouses with them, making permanent settlement feasible. However, focusing on this one characteristic rather than the entire migration pattern can obscure the importance of the sending country with consequences for how we interpret migrant practices and subject formation, as the case of Philippine migration suggests.

In Rhacel Parreñas' (2001) important book on migrant Filipina domestic workers, she compares Rome, Italy and Los Angeles, United States as receiving sites. She notes that the migration literature relies on the concept of "contexts of reception" to explain variation in immigrant outcomes. Contexts of reception include the labour markets, immigration laws and institutions that immigrants find and must interact with in a particular receiving site. Differences in the contexts of reception between countries, or even cities within the same country, mean that immigrants are literally "received" differently. This produces different immigrant outcomes (Bloemraad 2006; Menjívar 1999; Portes and Rumbaut 1996; Solari 2006b). Rather than look at economic or other quantifiable immigrant outcomes, Parreñas argues that migration should be understood as a "process of subjectification" and is interested in comparing migrant subjectivities (2001: 31). Rome and Los Angeles clearly do have different contexts of reception. Therefore, Parreñas suggests that, according to the migration literature, we should expect differences between migrants' experiences and the subjectivities produced in these two locations. However Parreñas found that Filipina migrant domestic workers in Rome and Los Angeles experienced what she calls "parallel lives" despite differing contexts of reception. She explains this by noting the shared social location of women, migrants, domestic workers with a "shared role as low-wage laborers in global capitalism" $(3,247)$. The argument implies that all women migrant domestic workers, by virtue of occupying the same structural location in global capitalism, should experience migration in similar ways. However, in my study of Ukrainian domestic workers, in virtually the same receiving sites as Parreñas' study, I found the opposite - divergent rather than parallel lives.

Migration is indeed a process of subjectification, and, as Parreñas suggests, "the macroprocesses of globalization should be given greater consideration when accounting for the influences of different contexts of reception on settlement" (2001: 247). Global processes should be taken into account when examining subject formation by comparing migration patterns as transnational fields. These migration patterns are shaped not merely in the abstract by "macroprocesses of globalization", but concretely through transnational processes that connect and shape sending and receiving countries. Global ethnographers excavate these transnational practices from the bottom up.

Ukrainian domestic workers in Rome and San Francisco are embedded in two divergent migration patterns that produce radically different migrant subjects. While there are similarities, now well documented in studies of domestic workers that focus on the labour process, in the micro-constellations of power between domestic workers performing cleaning and caring work in private homes and their employers in Rome and San Francisco, the meaning migrants attached to performing domestic labour and their lived experience differed dramatically. In the United States, 
informants were interested in speaking about the labour process, how it compared to pre-migration employment, and drawing lines of continuity by pointing out that in the Soviet Union they were "government workers", and they now had a similar relationship to the US state. Comparing "Soviet subjects" to "capitalist subjects", these migrants understood domestic work as signaling a particular position between "the free market" and the US state. Informants performing domestic work through a state agency juxtaposed their dependence on the state with their children's work in private industry. Their children's success was measured, not only in terms of their economic mobility through the market, but in their transformation into competent neoliberal subjects.

In Italy, the intricacies of performing cleaning and caring labour were not what interviewees understood as most salient in their lives. Rather, the particular confluence of gender, migration and social transformations that structured the migration pattern to Italy forced migrants into a painful relationship with the Ukrainian state. In this context, care work became a vehicle for Ukrainian nation-state building that involved a particular Europeanization project both at the level of nation and at the individual level of subject production. For many interviewees, migrating to be a care worker in Europe also involved cultivating what they considered a "capitalist" and European personal identity. They consciously remitted this cultural knowledge to their children back in Ukraine in the hope of giving them an advantage in navigating the post-Soviet economic and social order and in order to help create the new Ukraine. As one informant noted, "You cannot have a capitalist country without capitalists".

Therefore, the lived experiences of migration, including the type and intensity of transnational ties to Ukraine, the construction of national and civic identities, relationships to the receiving countries and the meaning assigned to the performance of domestic work all differed between Ukrainian migrants in Italy and those in the United States. The reason for this is not that receiving countries do not matter, but rather that sending countries do matter.

Migration studies tend to construct comparisons in two ways. The first is to compare different immigrant groups in the same receiving site. Once scholars control for socio-economic variables of the individual immigrants, the different immigrant groups are comparable and the sending country falls out of the analysis. Alternatively, as in Parreñas' study, immigrants from the same group in different receiving sites are compared. Here the sending country is considered a constant and it once again falls out of the analysis. However, given what we know about the routinized way that the Philippine state manages the migration process (Rodriguez 2010), it seems that Philippine migration to Italy and the United States includes two receiving sites, but only one migration pattern carefully managed by the Philippine state. From this analytical vantage point, it is unsurprising that Filipinas in different receiving sites engage in similar practices and have similar subjectivities because they are embedded in a single migration pattern.

In the case of Ukrainian migration to Italy and the United States, the sending country is not in fact a "constant". Sending and receiving countries interact to shape and limit the structural and discursive terrain. This results in subjects attributing 
different meanings to the "variables" ostensibly "held constant". Moving beyond describing a migration as temporary versus permanent, and taking seriously the differing effects of the sending country within each migration pattern, will help push the boundaries of migration theory.

Considering migration pattern as the unit of comparison also changes our analyses of sending states. Emigration is studied from the perspective of the sending country as a singular phenomenon. However, identifying different patterns opens up the possibility that not all migration patterns are created equal. As the next section argues, the migration patterns to Italy and the United States are differentially implicated in Ukraine's nation-statebuilding processes. This positions the Ukrainian case to make a third theoretical contribution to migration studies, which is to highlight the intersection of gender, migration and nation-state building through a comparison with other contemporary migrant sending states.

\subsection{Comparing Sending States: Gendered Nation-State Building and the Ukrainian State}

As we have seen, the transnational lens continues to grow in importance for migration studies. Some scholars argue that there is nothing new about transnationalism and that migrants of the Great European migrations to the United States at the turn of the twentieth century also engaged in transnational practices. Levitt (2001) argues that while transnationalism is not new, the form it takes and migrants' transnational experiences today do differ from those of the first half of the last century. For example, the proportion of the sending country population abroad has increased dramatically. The relationship between sending states and emigrants has also changed. Levitt notes that states used to reach out to emigrants hoping that they would return home to live. Today, many sending states offer dual citizenship and encourage emigrants to be long-distance nationals in an effort to cultivate migrant remittances and labour in transnational development projects (Levitt and Jaworsky 2007). She further argues that today, emigrants leave countries at more advanced stages of economic development and nation-state building than in the past, when most Southern European migrants left homelands without a clear sense of belonging to a particular nation-state (24). Contemporary migrants feel a greater sense of identification and obligation to their sending country. In fact, scholars argue that this allows for a convergence on a set of sending-state strategies that leverage migrants' sense of belonging to their home country to "manage" its population abroad (Fitzgerald 2009: 35).

Prominent among these strategies is the use of nationalism discourses to celebrate emigrants as "heroes" of the nation. The Philippine state institutionalized a labour export system that brokers temporary work contracts with receiving states in need of gendered and racialized labour (Rodriguez 2010). This is supported by state discourses that celebrate "migrant heroes" as saviours of the nation and enforced 
through the production of a "global Philippine citizenship". Nationalism discourses justify a robust web of overseas offices and consulates that offer Philippine migrant workers a measure of protection abroad, while simultaneously enforcing the obligations of citizenship, including the sending of remittances that are taxed by the state as an economic development strategy (Rodriguez 2002). The Mexican state engages in a similar strategy of "soft cultural nationalism" in order to maintain the loyalty of its population abroad and to secure the sending of remittances (Sherman 1999). Like the Philippines, the Mexican state also encourages the celebration of emigrants as "heroes" at local fiestas celebrating los hijos ausentes or its "absent children" (Fitzgerald 2009). State-organized Home Town Associations seek to include, as part of the Mexican nation, its population in the United States, including Mexican nationals, naturalized US citizens, and US-born citizens of Mexican descent, and turn them into "investors" in schools and infrastructure (Portes et al. 2007).

Ukraine, however, is not at an "advanced stage" of nation-state building. The Philippine state is able to publish a Handbook for Filipinos Overseas detailing how migrants are to behave as exemplary Filipino "ambassadors" (Constable 1997). For this to have power to shape the behaviour of Filipinos abroad, it must be based on a clearly defined national identity migrants are committed to upholding. This simply does not yet exist in Ukraine. After the collapse of the Soviet Union in 1991, both Ukrainian nationhood and Ukrainian statehood continued to be contested. A nationstatebuilding project in which there is overlap between Ukrainian ethnicity, language, culture and religion is just one of the many competing identity projects that have persisted in Ukraine since independence (Wilson 2000). As we have seen, Ukrainian emigration is involved in Ukrainian nation-state building, but not all migration patterns are involved in the same way. The migration pattern to the United States is less central to Ukrainian nation-state building, while the migration pattern to Italy is constitutive of it.

Migration from Soviet Ukraine to the United States was of concern to the Soviet state during the Cold War. Inside the Soviet Union, defection was considered a state crime and a "betrayal of the Fatherland". Defectors were tried and sentenced in absentia (Krasnov 1989). Defection was an embarrassment to the Soviet Union, and the United States welcomed Soviet defectors as evidence that they were winning the "war of ideologies". Therefore, in the context of the Cold War, migration to the United States had a symbolic significance that could compromise or bolster national prestige, which is no longer the case for today's post-Soviet Ukrainian migrants.

The migration to Italy, however, is intimately connected to Ukraine's future. Ukrainian nation-state building rests on a reorganization of family and work structures. Women are being squeezed out of the labour force, aided by a resurgence of biological determinism, in which discredited Soviet gender egalitarianism is replaced with discourses of gender difference and a celebration of women's "special" abilities as nurturing mothers and caretakers. These changes in gendered ideologies both reflect and help produce a shift in family structures from extended Soviet families, in which grandparents were primary caretakers of children while young parents were in the paid labour force, to nuclear families with a motherhousewife and a father-breadwinner as the ideal form. This shift to a "traditional" 
nuclear family is essential to the process of constructing Ukrainian national identity as "European" and "capitalist", and it is seen by the state as the building block of the market economy (Zhurzhenko 2004). These structural and discursive transformations doubly marginalize older women from both the labour market and their position in extended families. The physical removal of older women through migration produces nuclear families. More generally, it is remittances from migrant women labouring abroad in Italy and Europe that make a stay-at-home housewife economically feasible. In other words, the social transformations upon which processes of Ukrainian nation-state building rely are made possible, in part, through the labour migration of grandmothers.

A comparison of migration patterns not only sheds light on this nexus of gender, migration and nation-state building, but reveals that "emigration", from the point of view of the sending country, is not a monolithic and singular phenomenon. Once again the Ukrainian case offers us new insight into another aspect of migration studies, this time helping us think about how and why the sending country matters, even when our interest is migrant behaviours in the receiving context.

\subsection{Conclusions}

Scholars based in Europe have an intuitive sense of the importance of Ukrainian migration, perhaps because of the sheer number of people leaving Ukraine and heading to Western and especially Southern Europe, but those based in the United States are often asked: Who cares about Ukraine? There are three analytical reasons why migration scholars in particular should be interested in the Ukrainian case. First, as a still newly independent post-Soviet country, Ukraine is undergoing dramatic changes, including an economic transition from socialism to capitalism, the production of a new gendered order, and heightened processes of nation-state building. In the context of mass emigration, these complex processes of gendered economic change and nation-state building are occurring transnationally, challenging previous analytical frames characterized by methodological nationalism. Second, Ukraine draws our attention to the limitations of describing migration streams as either circular or permanent, challenging us to use migration patterns as our unit of analysis. The concept of migration patterns brings the sending country into our discussions and analyses of migrant practices and meaning-making in receiving countries. Finally, Ukraine challenges prevailing understandings of the relationship between a sending state and its emigrants. The Ukrainian case highlights that sending states have a more nuanced understanding of different migration patterns, which can have differential effects in the sending country. In these three areas of theorizing, the Ukrainian case pushes forward the boundaries of migration studies.

Ten years after the Orange Revolution described in the vignette at the beginning of this chapter, Ukraine is once again, through protests known collectively as Euromaidan, struggling to define itself as an independent country with a unified national identity. The current events in Ukraine are dramatic and include the ousting 
of former President Viktor Yanukovych in February 2014, Russia's annexation of the Ukrainian territory of Crimea the following month, and the continued fighting between Ukrainian government forces and Russian-backed militias. This is a symptom of the large middle ground between Ukrainian and Russian national identities (Wilson 2002). Without a stark line between these national identities, maintaining political boundaries has proven difficult. It is also a symptom of the unfinished work of the Orange Revolution and the continued contestation of Ukraine's nationbuilding processes. These play out inside Ukraine, but also abroad where Father Petro and Father Boryslav, themselves migrants in Rome, cultivate a national Ukrainian consciousness among labour migrants in the hope that these migrants will one day repatriate to help build the new Ukraine. Despite their importance to both the material and discursive constructions of Ukrainian nationalism, today, as during the Orange Revolution, emigrants are absent from discussions about Euromaidan in the media. Indeed, one of the realities of nation-state building processes in the twenty-first century is that they are likely transnational. The Ukrainian case can help us understand other cases of modern-day nation-state building, especially other former bloc countries forged in a similar context of post-socialism and post-colonialism. While the direction of Ukrainian nation-state building is uncertain, what is clear is that love and obligation to their nation will keep Ukrainian migrants in Europe intimately and painfully involved in what is to come.

\section{References}

Bloemraad, I. (2006). Becoming a citizen in the United States and Canada: Structured mobilization and immigrant political incorporation. Social Forces, 85(2), 667-695.

Burawoy, M. (1976). The functions and reproduction of migrant labor: Comparative material from Southern Africa and the United States. The American Journal of Sociology, 81(5), 1050-1087.

Burawoy, M. (2000). Introduction: Reaching for the global. In M. Burawoy, J. A. Blum, S. George, Z. Gille, \& M. Thayer (Eds.), Global ethnography: Forces, connections, and imaginations in a postmodern world (pp. 1-40). Berkeley: University of California Press.

CIA. (2011). "Population below poverty line (2003) by country": CIA world factbooks, December 18, 2003 to March 28, 2011. Retrieved October 10, 2013, from http://www.NationMaster.com/ graph/eco_pop_bel_pov_lineconomy-population-below-poverty-line \&date=2003.

Constable, N. (1997). Maid to order in Hong Kong: Stories of filipina workers. Ithaca: Cornell University Press.

Favell, A. (2008). The New face of East-West migration in Europe. Journal of Ethnic and Migration Studies, 34(5), 701-716.

Fitzgerald, D. (2009). A nation of emigrants: How Mexico manages its migration. Berkeley/Los Angeles: University of California Press.

Glick Schiller, N. (2009). A global perspective on migration and development. Social Analysis, 53(3), 14-37.

Hondagneu-Sotelo, P., \& Avila, E. (1997). "I'm Here, but I'm There": The meanings of Latina transnational motherhood. Gender and Society, 11(5), 548-568.

Krasnov, V. (1989). Soviet defectors: The Kgb wanted list. Stanford: Hoover Institution Press.

Levitt, P. (2001). The transnational villagers. Berkeley: University of California Press. 
Levitt, P., \& Glick Schiller, N. (2004). Conceptualizing simultaneity: A transnational social field perspective on society. International Migration Review, 38(3), 1002-1039.

Levitt, P., \& Jaworsky, B. N. (2007). Transnational migration studies: Past developments and future trends. Annual Review of Sociology, 33(1), 129-156.

Levitt, P., \& Lamba-Nieves, D. (2011). Social remittances revisted. Journal of Ethnic and Migration Studies, 37(1), 1-22.

Menjívar, C. (1999). Religious institutions and transnationalism: A case study of catholic and evangelical salvadoran immigrants. International Journal of Politics, Culture and Society, 12(4), 589-612.

Parreñas, R. S. (2001). Servants of globalization: Women, migration and domestic work. Stanford: Stanford University Press.

Parreñas, R. S. (2010). Homeward bound: The circular migration of entertainers between Japan and the Philippines. Global Networks, 10(3), 301-323.

Portes, A., \& Rumbaut, R. (1996). Immigrant America: A portrait. Berkeley: University of California Press.

Portes, A., Escobar, C., \& Radford, A. W. (2007). Immigrant transnational organizations and development: A comparative study. International Migration Review, 41(1), 242-281.

Ratha, D., Mohapatra, S., \& Silwa, A. (2011). Migration and remittances factbook 2011. Washington DC: The International Bank for Reconstuction and Development/The World Bank. (http://go.worldbank.org/U1S23A9QR0). Retrieved 23 June 2011.

Rodriguez, R. M. (2002). Migrant heroes: Nationalism, citizenship and the politics of filipino migrant labor. Citizenship Studies, 6(3), 341-356.

Rodriguez, R. M. (2010). Migrants for export: How the Philippine state brokers labor to the world. Minneapolis: University of Minnesota Press.

Sherman, R. (1999). From state introversion to state extension in Mexico: Modes of emigrant incorporation, 1900-1997. Theory and Society, 28(6), 835-878.

Solari, C. (2006a). Transnational politics and settlement practices: Post-soviet immigrant churches in Rome. American Behavioral Scientist, 49(11), 1528-1553.

Solari, C. (2006b). Professionals and saints: How immigrant careworkers negotiate gendered identities at work. Gender and Society, 20(3), 301-331.

Solari, C. (2014). 'Prostitutes' and 'Defectors': How the Ukrainian state constructs women emigrants to Italy and the USA. Journal of Ethnic and Migration Studies, 4O(11), 1817-1835.

Wilson, A. (2000). The Ukrainians: Unexpected nation. New Haven: Yale University Press.

Wilson, A. (2002). Elements of a theory of Ukrainian ethno-national identities. Nations and Nationalism, 8(1), 31-54.

Zhurzhenko, T. (2004). Strong women, weak state: Family politics and nation building in postsoviet Ukraine. In K. Kuehnast \& C. Nechemias (Eds.), Post-soviet women encountering transition: Nation building, economic survival, and civic activism (pp. 23-43). Baltimore: Johns Hopkins University Press.

Open Access This chapter is distributed under the terms of the Creative Commons AttributionNoncommercial 2.5 License (http://creativecommons.org/licenses/by-nc/2.5/) which permits any noncommercial use, distribution, and reproduction in any medium, provided the original author(s) and source are credited.

The images or other third party material in this chapter are included in the work's Creative Commons license, unless indicated otherwise in the credit line; if such material is not included in the work's Creative Commons license and the respective action is not permitted by statutory regulation, users will need to obtain permission from the license holder to duplicate, adapt or reproduce the material. 